МАШИНОБУДУВАННЯ

ТЕХНОЛОГІЯ МЕТАЛІВ

МАТЕРІАЛОЗНАВСТВО

MACHINE BUILDING

PROCESS METALLURGY

MATERIALS SCIENCE

UDC 621.928.9:669.18

A.A. Burov, $\mathrm{PhD}$,

A.I. Burov, DEng, Prof.,

L.V. Vinogradenko, Bachelor,

Odessa National Polytechnic University

\title{
GASES VACUUM DEDUSTING AND COOLING
}

Introduction. As a rule, to improve product quality, some additional production lines and equipment should be installed. The ladle degassing vacuum plant serves to extract the metal melts' unnecessary components and to add the required ones. Therefore, the enterprise can produce steels that can not be manufactured without vacuum technology use. The vacuum evacuation process is associated with dedusting and cooling of the exiting process gases. Requirements for the molten steel ladle degassing plant's dust control equipment are different from the requirements for equipment operating under normal conditions that is due to changes in amount, density and chemical composition of the process gases. Definitely, both choice and design of dust capturing equipment do affect the reliability and economic performance indexes of the entire ladle degassing system.

Analysis of recent research and publications. The multichannel dust collector (buran) with dusty gas flow vertical rotation axis includes a hopper and a system of serially linked closed-loop curved channels connected thereto with a curved slot [1]. Aggregates of solid particles are removed from the dusty gas which is further filtered through layers of fine dust in each channel. Dust entrainment with the treated gas follows the relation [1]

$$
C_{\text {fin }}=\frac{C_{\text {init }}}{1+2^{n-1}},
$$

where $C_{\text {init }}$ and $C_{f i n}$-inlet and outlet gas' dust burden;

$n$ - system's channels (closed loops) number.

The atmospheric emission comparable to the filter air dedusting is achieved at $n>10$. The validity of relation (1) is confirmed by the results accumulated over long-term operation of various burans at different enterprises under conditions close to normal ones [2].

The Aim of the Research is to analyze the possibilities to reduce environmental dust pollution by replacing cyclone with a buran equipped with four closed loops boiling steel ladle degassing system.

DOI 10.15276/opu.1.45.2015.03

(C) A.A. Burov, A.I. Burov, L.V. Vinogradenko, 2015

МАШИНОБУДУВАННЯ. ТЕХНОЛОГІЯ МЕТАЛІВ. МАТЕРІАЛОЗНАВСТВО 


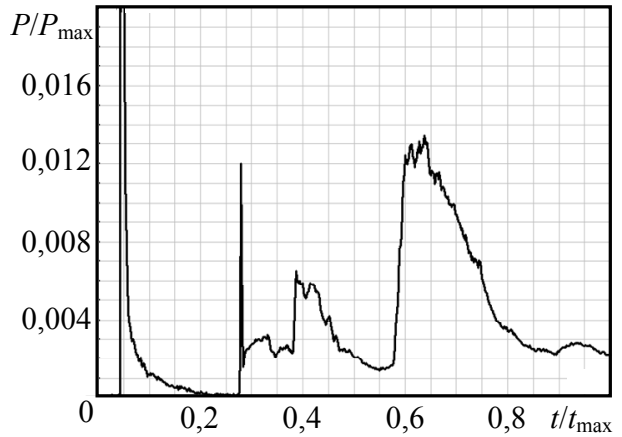

Fig. 1. Vacuum chamber pressure diagram: $P_{\max }=16639 \mathrm{~Pa}, t_{\max }=18 \mathrm{~min}$.

Main Body. The vacuum chamber internal pressure decreases from the atmospheric value reaching $0,5 \mathrm{mbar}$ during ladle degassing of 120 tons of molten steel [3].

That stepping-down is implemented through consecutive actuation of three different groups of vacuum rotary pumps. An assembly of fourteen parallel-connected vacuum pumps GV-400 (total capacity of $5600 \mathrm{Nm}^{3} / \mathrm{h}$ ) initially reduces the pressure from atmospheric to 100 mbar. Further actuated is an assembly of three pumps HV-14000 (total capacity of 42000 $\mathrm{Nm}^{3} / \mathrm{h}$ ) with pressure dropping up to 10 mbar. The working vacuum of about 0,5 mbar is registered upon actuation of the third assembly of pumps HV-30000 (total capacity of 120000 $\mathrm{Nm}^{3} / \mathrm{h}$ ). The pressure is temporarily increased when argon and nitrogen entering into the molten steel (Fig. 1).

The vacuum chamber and the boiling steel ladle are the main sources of vacuum plant process gases' dust pollution. The process gases removed from vacuum chamber contain argon, carbon dioxide, air, liquid and solid refractory particles and particles of powder additives to steel [4]. Submicron particles (less than 0,2 microns) make about $45 \%$ thereof, with particles of 5 microns size reaching $95 \%$ of the total post-dispersion weight. Volatile components released from the steel (alkaline metals, calcium, magnesium, manganese, etc.) are replaced in respective oxides with aluminium, silicium, carbon. Reduced metals interacting with the gas flow are forming the smallest nitride oxides, i.e. metal vapor condensation nuclei. Steel droplets taken out of the ladle by gases do harden when cooled. Thus, in the vacuum chamber and the gas duct formed are the heterogeneous systems with different physical and chemical properties, adversely affecting the vacuum rotary pumps and the environment.

Initially to decrease the vacuum rotary pumps and the environment dust burden we used a cylinder cyclone $(d=1600 \mathrm{~m})$ further replaced with a parallel-positioned vertical buran, $n=4$ (Fig. 2$)$.

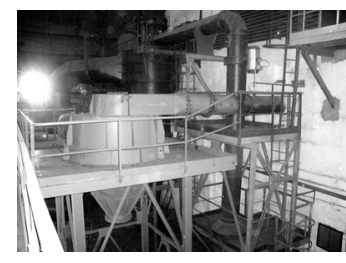

$a$

Fig. 2. Vertical buran and cyclone: general view (a), connection to the vacuum pumps station (b)

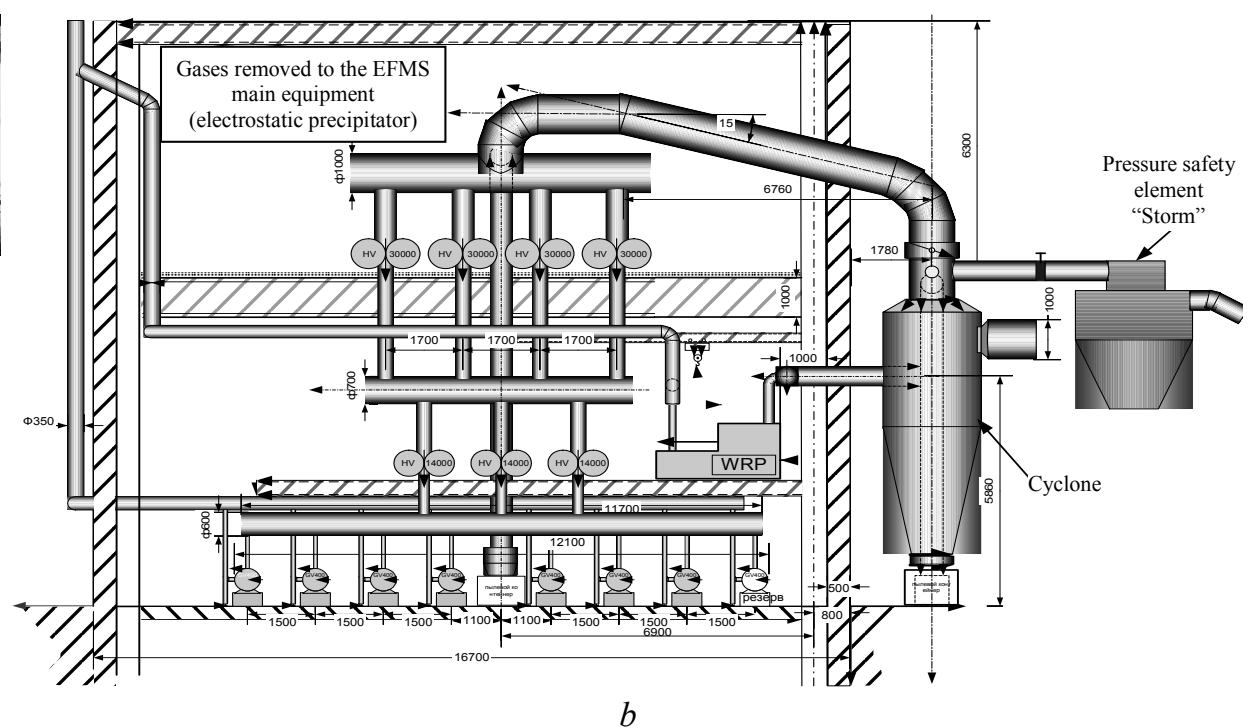

b

The gas duct ( $d=1000 \mathrm{~mm}$, initial section horizontally-positioned) connects the vacuum chamber to cyclone; the same diameter have the gas ducts at the cyclone output and the HV-30000 pumps manifold, the HV-14000 pumps manifold gas duct diameter is $700 \mathrm{~mm}$, and the GV-400 gas duct diameter is $600 \mathrm{~mm}$. The buran connecting ducts are $\varnothing 500 \mathrm{~mm}$ near the vacuum chamber and after the cyclone with gas ducts $\varnothing 1000 \mathrm{~mm}$. The buran's designed productivity makes $10^{4} \mathrm{Nm}^{3} / \mathrm{h}$.

Degasing the first 1080 tons of steel ( 9 test melts) resulted in accumulating such dust amounts: $18 \mathrm{~kg}$ at the cyclone inlet' gas duct, $10 \mathrm{~kg}$ at the cyclone, $10,4 \mathrm{~kg}$ at the manifold of $\varnothing 1000 \mathrm{~mm}, 3,3 \mathrm{~kg}$ 
at the protection grilles of HV-30000 pumps, $2 \mathrm{~kg}$ at the protection grilles of $\mathrm{HV}-14000$ pumps. The horizontal section of gas duct $\varnothing 1000 \mathrm{~mm}$ together with the cyclone extracted from process gases up to $70 \%$ of overall dust weight accumulated at the gas duct. At the issue of degasing 1800 tons of steel the $36 \mathrm{~kg}$ of process gas dust are extracted at the gas duct and $25 \mathrm{~kg}$ are collected by the cyclone.

The buran collected $7 \mathrm{~kg}$ of dust upon degasing 120 tons of steel and $67 \mathrm{~kg}$ of dust have been discharged from the plant having degased 1680 tons of steel (Fig. 3).
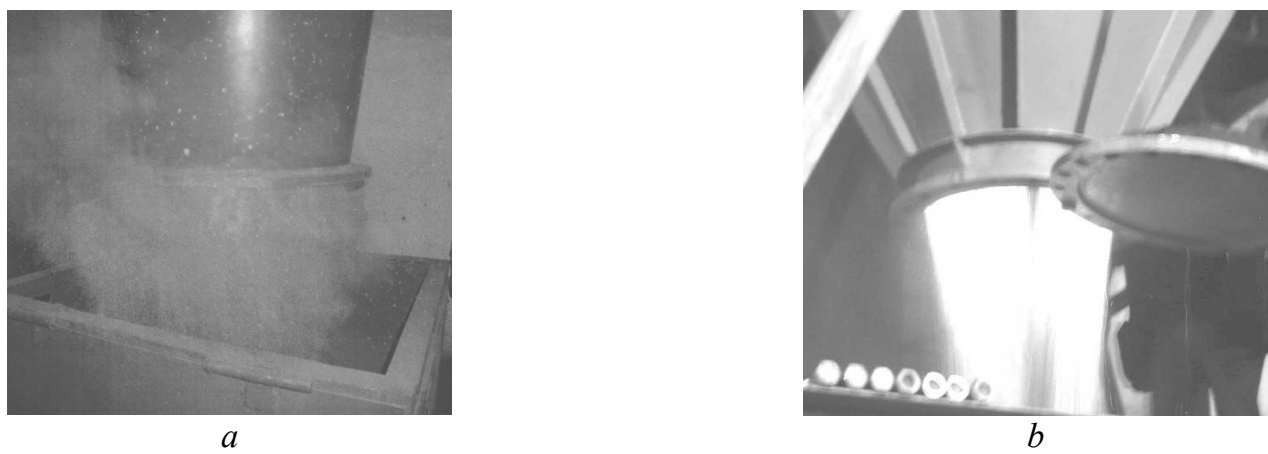

Fig. 3. Discharging the trapped dust: from cyclone (a), from buran (b)

The buran provided degassing of 1800 tons liquid steel without revision and dust removal of rotary pumps HV-30000 grilles; the cyclone productivity was 3 times below [5]. Bright glow of magnesium oxidized in air does evidence its significant amounts at the discharged dust. There arises the Ranque intense thermal effect at the channels system with gas swirling flow central regions' peripheral heating and cooling as shown in Fig. 4, $a$. Straightening the output swirling flow at the outlet and the circulation in closed hot dusty gas circuits do create an intense forevacuum effect increasing the rotary pumps station productivity (Fig. $4, b$ ).
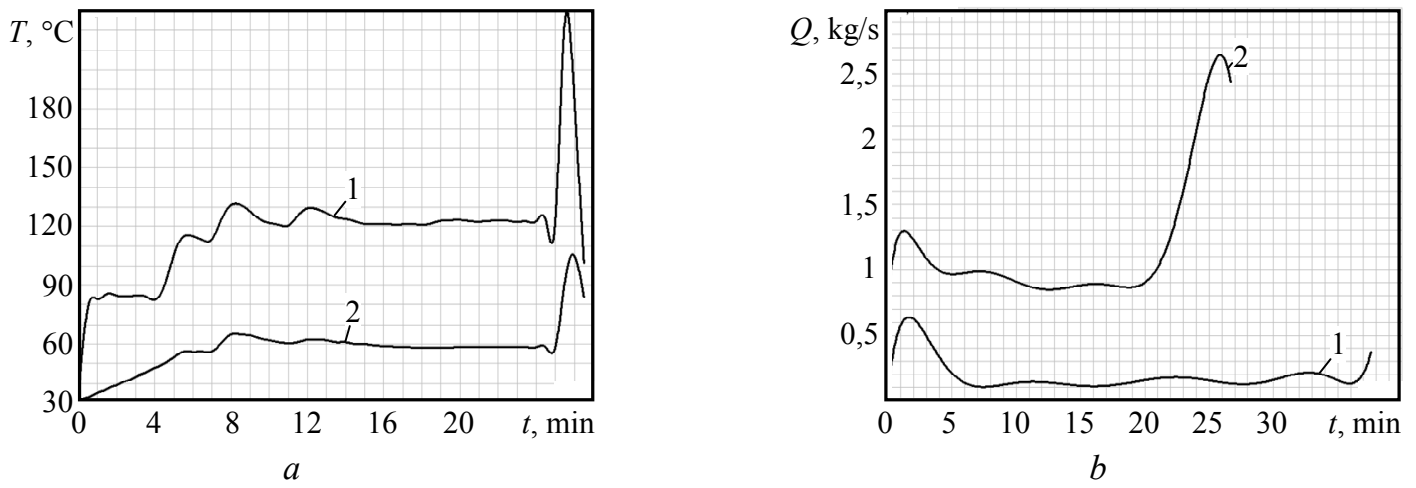

Fig. 4. Thermal and forevacuum effects of the vertical buran, $n=4$ : inlet (1), outlet (2) (a); cyclone (1), buran (2) (b)

Average decrease of the transit technological gas flow temperature at the storm plant $(n=4)$ makes 2-folds. Replacing the cyclone with a vertical storm plant we increased the vacuum rotary pumps station productivity for $40 \%$ having $1 / 3$-reduced (from 37 to 25 minutes) the time of ladle degassing the 120 tons of molted steel.

The vacuum rotary pumps GV-400 are parallel-installed in two rows on the first floor of the pumps station (Fig. 2). They are actuated the first and reduce the pressure at vacuum chamber from atmospheric value to $100 \mathrm{mbar}$, further providing pressure of $0,5 \mathrm{mbar}$ via forepumps (HV-1400 and HV-30000), compressing the process gas. Pumps GV-400 do emit process gases into atmosphere. The pump GV-400 No. 5 is preceded with a horizontal buran, allowing to connect the hopper with systems of four and six curved channels with closed loops (Fig. 5). The neighboring pump No. 7 has been studied to compare its results with these of the pump No. 5. 


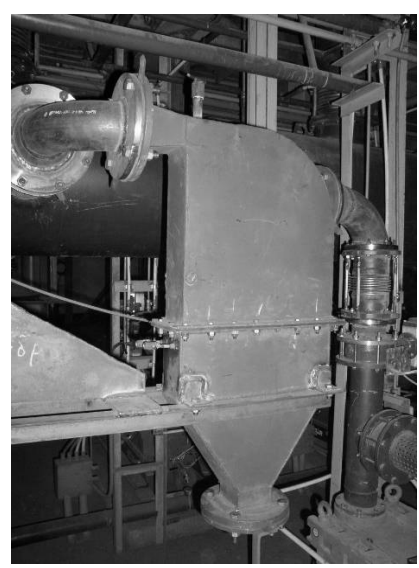

Fig. 5. Horizontal buran, $n=4$

The burans bearing $n=4$ and $n=6$ gave practically equal indexes of fine-dispersion dust emission into atmosphere when non-stationary (initial) and stationary (final) conditions of liquid steel degassing. At the first case emission dustiness index at the pump's No. 7 inlet was $1,4 \mathrm{~g} / \mathrm{m}^{3}$ and $0,7 \mathrm{~g} / \mathrm{m}^{3}$ at the pump No. 5 , and respective ciphers for the second case were 0,15 and $0,07 \mathrm{~g} / \mathrm{m}^{3}$. The buran's dust suppression coefficient $\eta=0,5$ is maintained at 10 -folds variations of gas consumption and dust content at process gas.

The horizontal buran $(n=4)$ cooled the process gas under stationary conditions from 50 to $17^{\circ} \mathrm{C}$ (Fig. 6, a) and 5 time augmented the GV-400 rotary vacuum pump productivity (Fig. 6, b).
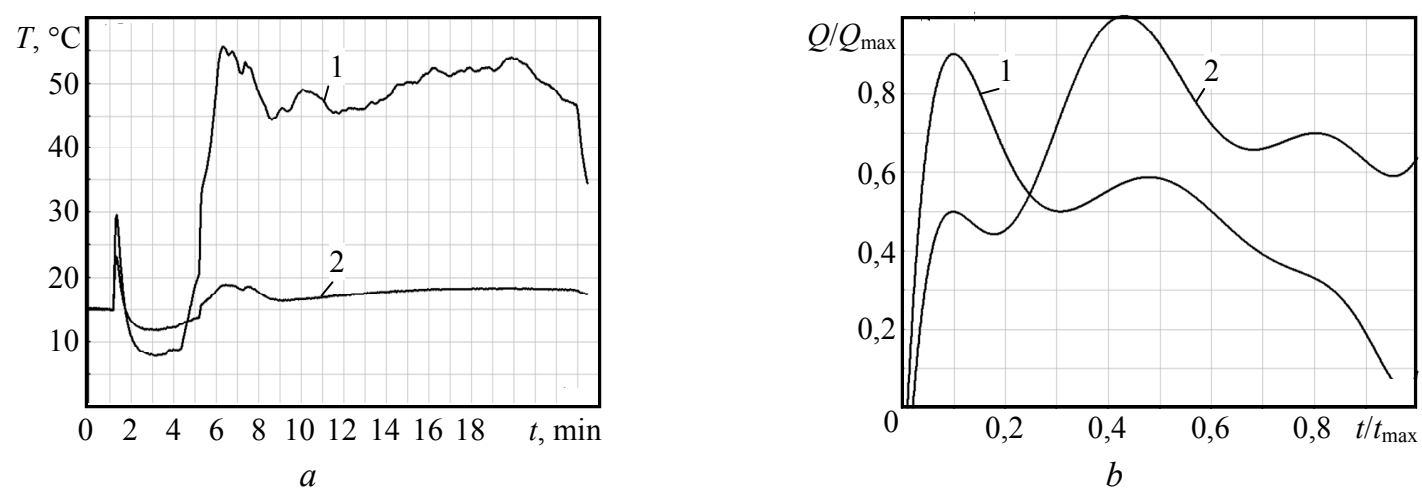

Fig. 6. Thermal and forevacuum effect of a horizontal buran, $n=4$ : inlet (1), outlet (2) (a); pump No. 5 (1), pump No. 7 (2), $t_{\max }=12 \mathrm{~min}, Q_{\max }=456 \mathrm{~m}^{3} / \mathrm{h}(\mathrm{b})$

Results. Replacing the cyclone with a vertical buran $(n=4)$ we 5 -times decreased the dust atmospheric emission, increasing the vacuum rotary pumps station productivity for $40 \%$, the capital and operational expenses reduced, concurrently the time of ladle degassing the 120 tons of boiling steel is $1 / 3$-shortened. The technological gases cooling and dedusting resulting from research of closed-loops buran allows to install and efficient operation of bag filter at the plant's outlet.

Conclusions. The closed-loop connected curvilinear channels system creates conditions for the negative feedbacks' emergence at a gas flow with curved transit and circulating streams. They are embodied with circulating flows connecting the inputs and outputs of the whole system each channel. Multiple continuous transit flow filtration through circulating dust layers leads to the formation and accumulation of particles' aggregates at the hopper. The validity of such dusty flow control mechanism using complex probabilistic systems is confirmed by experimental data obtained in a vacuum. Therefore, we consider promising to replace one of the buran's two fore pumps groups with the required number of curved canals (closed loop).

\section{Література}

1. Аппарат с замкнутыми контурами / С.А. Балан, А.А. Буров, А.И. Буров, Д.А. Серебрянский // Сб. науч. статей $\mathrm{X}$ юбилейной Международной научно-практической конференции “Экология и здоровье человека. Охрана воздушного и водного бассейнов. Утилизация отходов”, 10-14 июня 2002 г., Щелкино, АР Крым / Укр. гос. науч.-техн. центр “Энергосталь”. — Харьков, 2002. — T. 2. - C. $320-325$. 
2. Оценка эффективности пылеулавливания в вакуумной установке / С.А.Балан, А.А. Буров, Д.А. Серебрянский, А.П. Лепихин // Тр. Одес. политехн. ун-та. - 2002. - Спецвыпуск. - С. $21-23$.

3. Использование пылеуловителей новой конструкции вместо циклонов / А.П. Лепихин, И.В. Деревянченко, А.А. Буров, Д.А. Серебрянский // Металлург. — 2004. - № 5. - С. $52-55$.

4. Буров, А.А. Эксплуатация буранов на металлургическом заводе / А.А. Буров // Сб. науч. статей XVI Международной научно-практической конференции “Экология и здоровье человека. Охрана воздушного и водного бассейнов. Утилизация отходов”, 2-6 июня 2008 г., Щелкино, АР Крым / Укр. гос. науч.-техн. центр “Энергосталь”. - Харьков, 2008. - Т. 1. - С. $410-414$.

5. Центробежная очистка промышленных выбросов в атмосферу / А.А. Буров, А.И. Буров, А.В. Силин, О.Н. Цабиев // Екологія довкілля та безпека життєдіяльності. — 2005. - № 6. C. $44-51$.

\section{References}

1. Balan, S.A., Burov, A.A., Burov, A.I. and Serebryanskiy, D.A. (2002). Apparatus with closed contours. In S.V. Razmetaev (Ed.), Proceedings of $10^{\text {th }}$ International Scientific and Practical Conference "Ecology and Human Health. Protection of Air and Water. Disposal of Waste". (vol. 2, pp. 333-338). Kharkiv: SCIM UkrWodGeo.

2. Balan, S.A., Burov, A.A., Serebryanskiy, D.A. and Lepihin, A.P. (2002). Rating of a dust-catching efficiency in the vacuum installation. Odes 'kyi Politechnichnyi Universytet. Pratsi, 3, 21-23.

3. Lepchin, A.P., Derevyanchenko, I.V., Burov, A.A. and Serebryansky, D.A. (2004). Use of dust collectors (new construction) instead of cyclones. Metallurgist, 5, 52-55.

4. Burov, A.A. (2008). Operation of Burans at a metallurgical plants. In S.V. Razmetaev (Ed.), Proceedings of $16^{\text {th }}$ International Scientific and Practical Conference "Ecology and Human Health. Protection of Air and Water. Disposal of Waste" (vol. 1, pp. 410-414). Kharkiv: SCIM UkrWodGeo.

5. Burov, A.A., Burov, A.I., Silin, A.V. and Tsabiev, O.N. (2005). Centrifugal purification of industrial emissions into the atmosphere. Environment Ecology and Safety of Life Activity, 6, 44-51.

\section{АНОТАЦІЯ / АННОТАЦИЯ / ABSTRACT}

О.О. Буров, О.І. Буров, Л.В. Винограденко. Обезпилювання та охолодження газів в вакуумі. Представлено результати експлуатації вакуумної установки позапічної дегазації 120 т рідкої сталі з різними пиловловлювачами. Отримані при дослідженні бурану з замкнутими контурами охолодження і обезпилювання технологічних газів забезпечило встановлення та експлуатацію після нього рукавного фільтра. Доведено ефективність заміни циліндричного циклону багатоканальним пиловловлювачем (бураном) з вертикальною віссю обертання запиленого газового потоку, в основі якого лежить система послідовно з'єднаних криволінійних каналів із замкненими контурами (зворотними зв'язками). Система послідовно з'єднаних криволінійних каналів із замкненими контурами створює умови для виникнення в газовому криволінійному перебігу з транзитними і циркулюючими потоками негативних зворотних зв'язків. Вони реалізуються циркулюючими потоками, що з'єднують виходи і входи кожного каналу всієї системи. Багаторазова безперервна фільтрація транзитного потоку через шари циркулюючого пилу призводить до утворення і накопичення в бункері агрегатів частинок. Справедливість такого механізму управління запиленими потоками підтверджується отриманими в вакуумі дослідними даними. Представляється перспективною заміна однієї 3 двох груп форвакуумних насосів бурану з необхідною кількістю криволінійних каналів.

Ключові слова: вакуум, система каналів, пил, газ, рідка сталь, охолодження.

А.А. Буров, А.И. Буров, Л.В. Винограденко. Обеспыливание и охлаждение газов в вакууме. Представлены результаты эксплуатации вакуумной установки внепечной дегазации 120 т жидкой стали с различными пылеуловителями. Полученные при исследовании бурана с замкнутыми контурами охлаждение и обеспыливание технологических газов обеспечило установку и эксплуатацию после него рукавного фильтра. Доказана эффективность замены цилиндрического циклона многоканальным пылеуловителем (бураном) с вертикальной осью вращения запылённого газового потока, в основе которого лежит система последовательно соединённых криволинейных каналов с замкнутыми контурами (обратными связями). Система последовательно соединенных криволинейных каналов с замкнутыми контурами создает условия для возникновения в газовом криволинейном течении с транзитными и циркулирующими потоками отрицательных обратных связей. Они реализуются циркулирующими потоками, соединяющими выходы и входы каждого канала всей системы. Многократная непрерывная фильтрация транзитного потока через слои циркулирующей пыли приводит к образованию и накоплению в бункере агрегатов частиц. Справедливость такого механизма управления запыленными потоками подтверждается полученными в вакууме опытными данными. Представляется перспективной замена одной из двух групп форвакуумных насосов бурана с необходимым числом криволинейных каналов.

Ключевые слова: вакуум, система каналов, пыль, газ, жидкая сталь, охлаждение. 
A.A. Burov, A.I. Burov, L.V. Vinogradenko. Gases vacuum dedusting and cooling. Represented are the results of operating the ladle degassing vacuum plant (productivity: 120 tons of liquid steel) with various dust collectors. The process gases' cooling and dedusting, obtained in the closed loop buran study, provides opportunity to install a bag filter after that closed loop and its efficient use. Proven is the effectiveness of the cylindrical cyclone replacement with a multichannel (buran) dust collector, based on a system of closed-loop (return coupling) serially connected curved ducts, where the dusty gas flow rotation axis is vertically positioned. The system of closed-loop serially connected curvilinear channels creates preconditions for the emergence of a negative feedback at the curvilinear gas flow containing transit and circulating flows. These conditions are embodied with circulating flows connecting the in- and outputs of the whole system's each channel. The transit flow multiple continuous filtration through the circulating dust layers leads to the formation and accumulation of particles' aggregates in the collection chamber. The validity of such a dusty flow control mechanism is confirmed by experimental data obtained in a vacuum chamber. Therefore, replacing one of the two buran's forevacuum pumps assemblies with the necessary number of curved channels (closed loop) is estimated in a promising method.

Keywords: vacuum channel system, dust, gas, molten steel, cooling.

Received November 17, 2014 